SAINS TANAH - Journal of Soil Science and Agroclimatology

Journal homepage: http://jurnal.uns.ac.id/tanah

\title{
Phosphorus availability as affected by the application of organic amendments in Ultisols
}

\author{
Zainal Muktamar*, Lifia, Teguh Adiprasetyo \\ Department of Soil Science, Bengkulu University, Muara Bangka Hulu, Bengkulu, Indonesia
}

\begin{tabular}{|c|c|}
\hline ARTICLE INFO & ABSTRACT \\
\hline $\begin{array}{l}\text { Keywords: } \\
\text { Available P } \\
\text { Cattle manure } \\
\text { Chicken manure } \\
\text { Ultisols } \\
\text { Vermicompost } \\
\text { Article history } \\
\text { Submitted: 2020-04-22 } \\
\text { Accepted: 2020-06-11 } \\
\text { * Corresponding Author } \\
\text { Email address: } \\
\text { muktamar@unib.ac.id }\end{array}$ & $\begin{array}{l}\text { The adequacy and availability of phosphorous (P) in the soil during the organic matter } \\
\text { decomposition are important for plant growth, especially in the early stages since most } \\
\text { organic matter slowly release plant nutrients. Therefore, this study was conducted to } \\
\text { determine the availability of } \mathrm{P} \text { during organic amendments in Ultisols. The incubation } \\
\text { experiment used a Completely Randomized Design (CRD) for } 7 \text { treatments which consisted } \\
\text { of vermicompost, chicken, and cattle manure at the rate of } 15 \text { and } 30 \mathrm{Mg} \text { ha }{ }^{-1} \text {. Soil and } \\
\text { organic amendments were incorporated into a } 5 \mathrm{~kg} \text { polybag and the mixture was incubated } \\
\text { for } 7 \text { weeks. The soil was sampled at the } 2,3,4,5,6 \text {, and } 7 \text { weeks, and analyzed for } \mathrm{P} \\
\text { availability and pH. Also, the Total Soil Organic Carbon (TSOC), Total Soil Nitrogen (TSN), } \\
\text { exchangeable Al, and Cation Exchange Capacity (CEC) were analyzed from the soil sampled } \\
\text { either at week } 4 \text { or } 7 \text {. The result showed that P increased slowly in the first } 3 \text { weeks of } \\
\text { incubation, followed by a drastic continuous increase in week } 4 \text {. The experiment also } \\
\text { confirmed that chicken manure released the highest and fastest amount of P to the soil as } \\
\text { compared to vermicompost, and cattle manure. On average, the increment of P was } 2.28 \text {, } \\
\text { 1.71, and } 1.97 \text { mg kg }{ }^{-1} \text { week }{ }^{-1} \text { for chicken manure, vermicompost, and cattle manure } \\
\text { respectively. Furthermore, the improvement of soil chemical properties was achieved } \\
\text { using amendment as indicated by the increase in TSN, soil pH, and a decrease in } \\
\text { exchangeable Al. The result was significant for } \mathrm{P} \text { organic fertilization to ensure its } \\
\text { availability for plant growth, leading to improved productivity, especially in organic farming } \\
\text { systems. }\end{array}$ \\
\hline
\end{tabular}

How to Cite: Muktamar, Z., Lifia, and Adiprasetyo, T. (2020). Phosphorus availability as affected by the application of organic amendments in Ultisols. Sains Tanah Journal of Soil Science and Agroclimatology, 17(1): 16-22 (doi: 10.20961/stjssa.v17i1.41282)

\section{Introduction}

The main challenges of Ultisols are low phosphorus availability, soil organic matter, $\mathrm{pH}$, and high aluminum saturation (Anggita et al., 2018; Peng et al., 2011; Prasetyo \& Suriadikarta, 2006), which lead to plant toxicity. Ultisols from Kandang Limun, Bengkulu contained $9.96 \mathrm{mg} \mathrm{kg}^{-1} \mathrm{P}, 66.3 \mathrm{mg}$ $\mathrm{kg}^{-1}$ exchangeable $\mathrm{K}, 113 \mathrm{mg} \mathrm{kg}^{-1} \mathrm{Al}$, and soil $\mathrm{pH}$ of 4.50 (Muktamar et al., 2016). Another Ultisols has $0.18 \%$ of total soil nitrogen (TSN), $7.77 \mathrm{mg} \mathrm{kg}^{-1} \mathrm{P}, 367 \mathrm{mg} \mathrm{kg}-1 \mathrm{Al}$, and $\mathrm{pH}$ of 4.90 (Sianturi et al., 2019). Low P in acid soil is associated with the formation of Al or Fe-phosphate complex which is insoluble in soil solution (Dotaniya et al., 2014). Therefore, organic amendment is commonly used to improve soil fertility.

Organic fertilizer is the only source of plant nutrients in organic farming practices (Fahrurrozi et al., 2016; Melero et al., 2008). The amendment can be prepared from different sources and used as a substitute for synthetic fertilizer. Some of the sources are chicken, and cattle wastes. Chicken manure contains $2.40 \%-3.60 \% \mathrm{~N}, 1.56 \%-2.80 \% \mathrm{P}_{2} \mathrm{O}_{5}$, and $1.40 \%$ 2.31\% $\mathrm{K}_{2} \mathrm{O}$ (Amanullah et al., 2010). On average, cattle manure has $1.55 \% \mathrm{~N}, 0.80 \% \mathrm{P}_{2} \mathrm{O}_{5}, 0.96 \% \mathrm{~K}_{2} \mathrm{O}$ (Tennakoon \& Bandara, 2003). Another organic fertilizer frequently applied as a source of plant nutrient is vermicompost, which contains $2.15 \% \mathrm{~N}, 0.54 \% \mathrm{P}_{2} \mathrm{O}_{5}$, and $0.66 \% \mathrm{~K}_{2} \mathrm{O}$ (Muktamar et al., 2017).

Organic matter is an important source of soil phosphorus, and several studies reported that the application of organic amendments improved the availability of soil phosphorus. Also, the application of vermicompost linearly increased the content in Ultisols (Sianturi et al., 2019). Previous studies confirmed that there was a significant increase in extractable 
phosphorus when dairy manure was applied (Mohammadi et al., 2009).

The major drawback of organic fertilizer is its slow release of plant nutrients such as phosphate, which is not often available when needed, especially at the growing stage. Rita et al. (2013) stated that the mineralization of organic phosphorus provided a significant increase in inorganic $P$ after 9 weeks incubation. Also, Dotaniya et al. (2014) stated that the phosphorus content of Inceptisols continuously increased after 6 and 12 months of organic incubation. According to Seufert et al. (2012), crop yield from organic farming ranged from 5\%-35\% which is lower than the conventional practices. Nutrient adequacy and availability are very important in ensuring crop growth. Also, nutrient availability during organic decomposition has not been extensively identified. Therefore, this study aimed to determine $P$ availability during the organic amendments in Ultisols.

\section{Materials and Method}

\subsection{Experimental design}

The incubation experiment was conducted from May-June 2019 in Soil Science Greenhouse, Faculty of Agriculture, University of Bengkulu. A Completely Randomized Design (CRD) was used for 7 treatments. The treatments consisted of vermicompost, chicken manure, and cattle manure of 15 , and $30 \mathrm{Mg} \mathrm{ha}{ }^{-1}$ respectively, and control. Each treatment was replicated 3 times.

\subsection{Soil sampling and organic amendments preparation}

Ultisols was sampled from Beringin Raya Village, Bengkulu at an altitude of $15 \mathrm{~m}$ above sea level, and a composite soil was collected from the surface layer $(0-20 \mathrm{~cm})$. The sample was air-dried for 2 days and sieved with a $5 \mathrm{~mm}$ screen. Also, an undisturbed soil was collected to determine the bulk density and for calculating amendment weight per polybag. The soil contained $2.45 \mathrm{mg} \mathrm{kg}^{-1} \mathrm{P}$ (Bray I method), $30.8 \mathrm{~g} \mathrm{~kg}^{-1}$ Total Soil Organic Carbon (TSOC) (Walkley and Black), 20.87 $\mathrm{cmol} \mathrm{kg}{ }^{-1}$ Cation Exchange Capacity (CEC) (Ammonium Acetate extraction), and $21.0 \mathrm{~g} \mathrm{~kg}^{-1}$ Total Soil Nitrogen (TSN) (Micro Kjeldahl method). Furthermore, the soil contained $2.26 \mathrm{cmol} \mathrm{kg}^{-1}$ exchangeable $\mathrm{Al}(\mathrm{KCl}$ extraction method) with a pH (Electrometric method) of $4.23,45.32 \%$ clay, $19.20 \%$ silt, and $35.48 \%$ sand (textural classification of sandy clay) (Hydrometric method).

The vermicompost was prepared by loading $500 \mathrm{~kg}$ dairy cattle wastes in a $2 \times 4 \mathrm{~m}^{2}$ composting house, and $10 \mathrm{~kg}$ worms were placed in each corner of the floor. The waste was kept moist and incubated for 1 month. After incubation, vermicompost was collected from the upper part of the pile which had $0.35 \% \mathrm{P}, 1.07 \% \mathrm{~N}$, and $10.6 \% \mathrm{C}$ with a $\mathrm{C} / \mathrm{N}$ ratio of 9.9. Also, the chicken and cattle manure were bought from a fertilizer store. The chicken manure contained $0.48 \% \mathrm{P}, 1.19 \%$ $\mathrm{N}$, and $8.06 \% \mathrm{C}$ with a $\mathrm{C} / \mathrm{N}$ ratio of 6.8 , while cattle manure comprised of $0.20 \% \mathrm{P}, 0.74 \% \mathrm{~N}$, and $7.69 \% \mathrm{C}$ with $\mathrm{C} / \mathrm{N}$ ratio of 10.4 .

\subsection{An incubation experiment}

The organic amendments were weighed according to each treatment and incorporated with a $5 \mathrm{~kg}$ air-dried soil sample. Distilled water was then transferred into the polybag and randomly placed on a $1 \mathrm{~m}$ high wooden stand in the greenhouse. This was followed by incubating the sample for 7 weeks and continuously maintained at field capacity by the daily addition of distilled water.

The soil mixture was sampled at weeks 2, 3, 4, 5, 6, and 7 using a small probe, air-dried, sieved, and analyzed for $\mathrm{P}$ using the Bray method. Furthermore, the soil acidity was analyzed using a $\mathrm{pH}$ meter at a 1:1 ratio of soil and distilled water. The soil samples collected at weeks 4 and 7 were also analyzed for TSOC using the Walkley and Black method and TSN using the Micro Kjeldahl method. A sample collected at week 7 was analyzed for exchangeable Al using the titration method after extraction by $1 \mathrm{~N} \mathrm{KCl}$, and $\mathrm{CEC}$ using the extraction method with $1 \mathrm{~N} \mathrm{NH}_{4} \mathrm{OAc}$ (Balai Penelitian Tanah, 2009).

\subsection{Statistical analysis}

Data were analyzed for ANOVA using SAS version 9.1.3. portable at $p<0.05$. The treatments were separated using orthogonal contrast analysis and $\mathrm{P}$ availability during the incubation was analyzed using repeated measurement at the probability level of 0.05 .

\section{Results}

\subsection{Soil phosphorous availability}

In general, the availability of $\mathrm{P}$ in soil continuously increased during 7 weeks of incubation as shown in Figure 1. A slight increase was observed in the first 3 weeks but it was more substantial at the end of the incubation period. Repeated measurements showed there was no significant increase during the first 2 weeks $(p<0.05)$. Available $P$ in the control treatment was consistently lower than those with organic amendments, which means there was phosphorous release from organic materials. The highest soil $P$ was detected in the chicken manure treatment at $30 \mathrm{Mg} \mathrm{ha}^{-1}$. At the end of the incubation, contrast analysis showed the organic amendments enhanced $\mathrm{P}$ availability by $90.8 \%$.

Figure 1 also showed chicken manure was superior to the other two organic amendments. After a week incubation, the average available $\mathrm{P}$ in the soil treated with chicken manure was $28.7 \%$ and $11.4 \%$ higher than vermicompost and cattle manure respectively. However, at the end of the incubation, the percentage decreased to $10.9 \%$ and $4.2 \%$, respectively. Meanwhile, during decomposition, treatments of vermicompost and cattle manure released a comparable amount of $P$ to the soil. In general, a higher rate of organic amendments provided greater phosphorus. Therefore, organic amendments at $30 \mathrm{Mg} \mathrm{ha}^{-1}$ provided $11.1 \%$ higher phosphorus. 


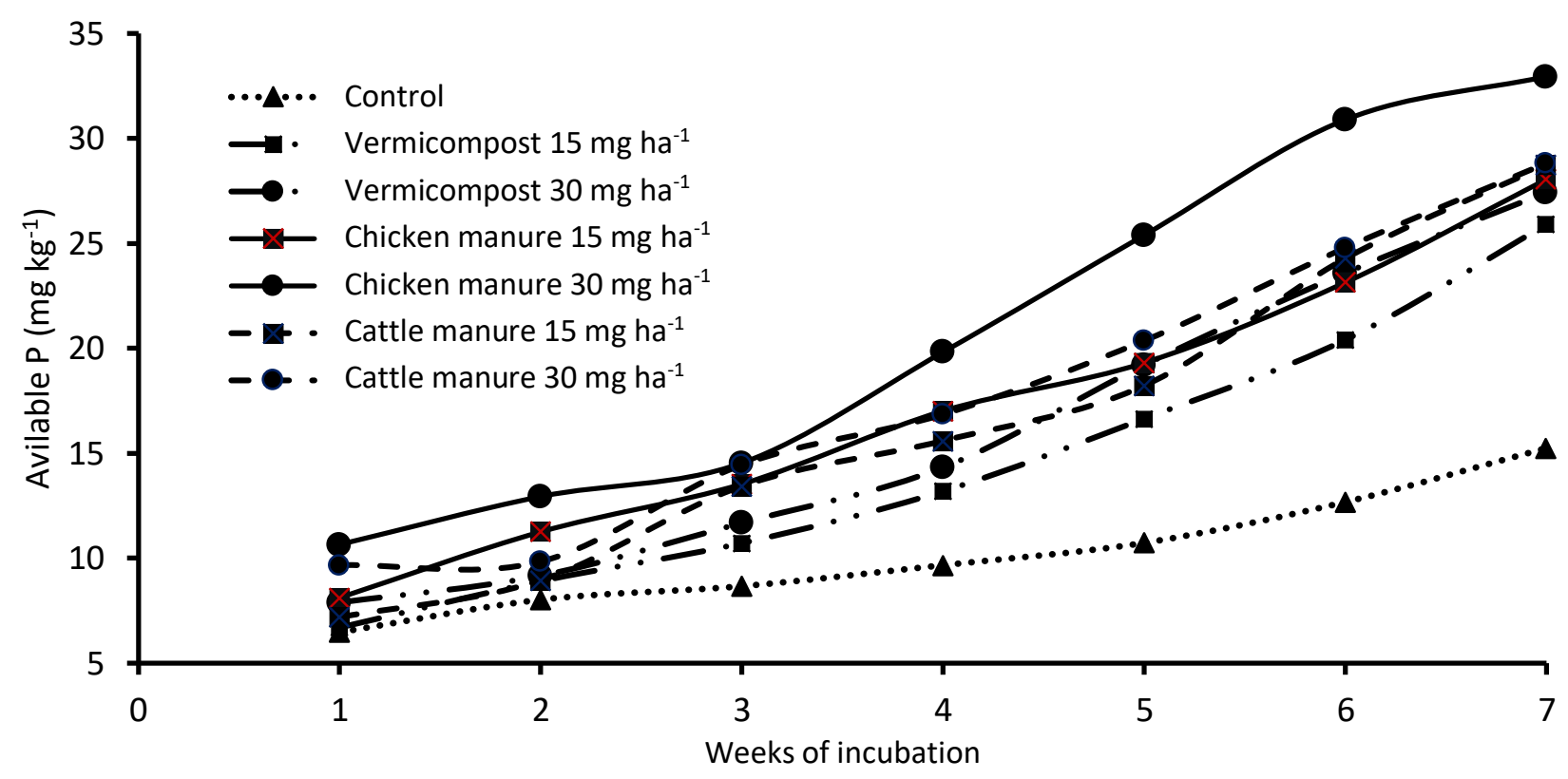

Figure 1. Periodical availability of $P$ during the incubation

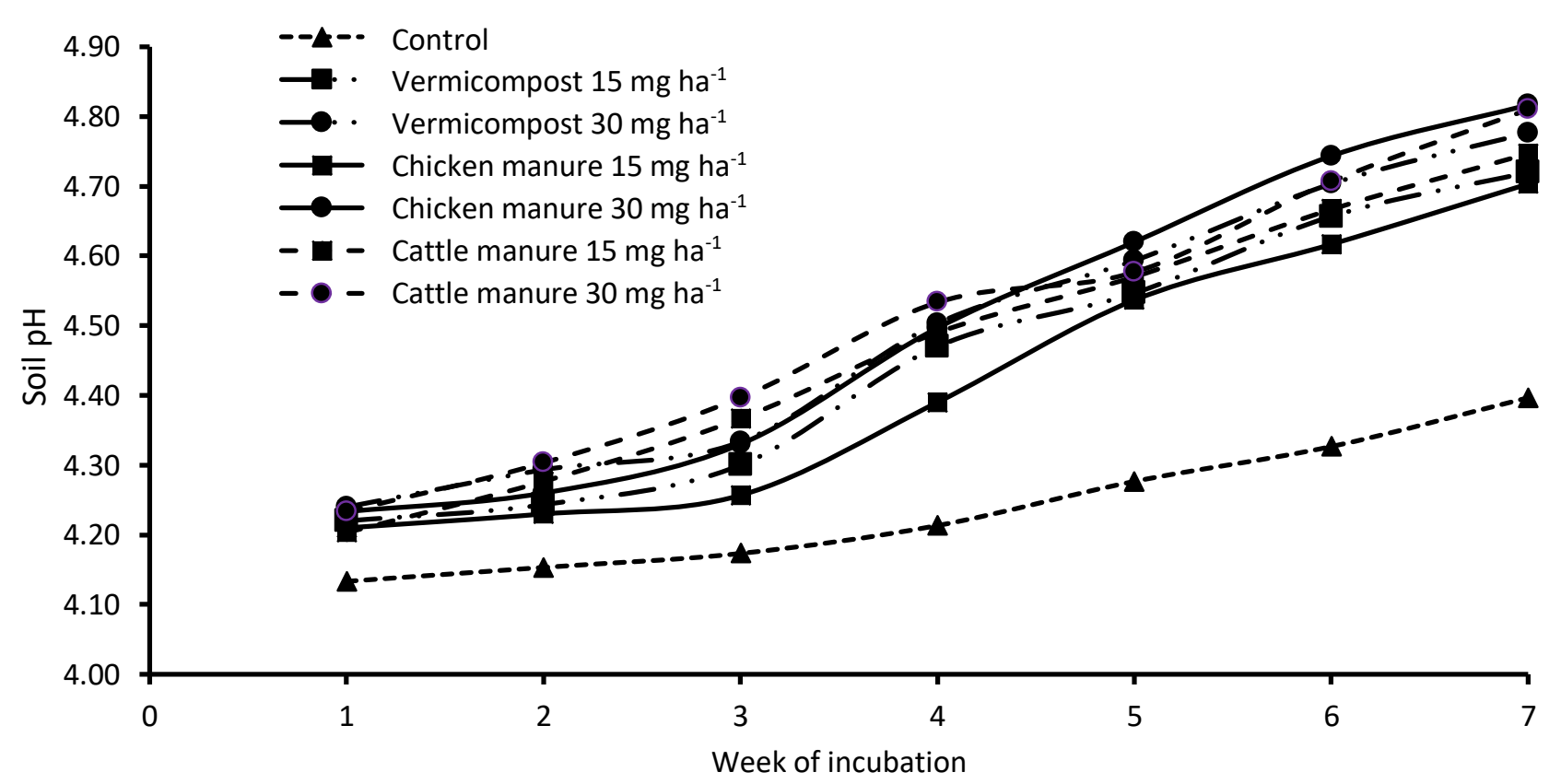

Figure 2. Soil pH during the incubation as affected by organic amendments

\subsection{Soil $p H$}

The availability of phosphorus was accompanied by a sluggish rise in $\mathrm{pH}$ during the first 3 weeks and significantly increased afterward (Figure 2). In general, the application of the organic amendments exhibited a consistently higher soil $\mathrm{pH}$ throughout the incubation. The $\mathrm{pH}$ difference between the treated soil and control increased, especially after week 3. Contrast analysis showed that at the end of incubation, the $\mathrm{pH}$ was $7.3 \%$ higher in treated soil than control. In addition, it was observed that the $\mathrm{pH}$ was not significantly different in the soil treated with organic amendments.

\subsection{Total soil organic carbon}

Total soil organic carbon was much lower at the end of the incubation when compared to week 4 (Figure 3). The greatest decrease was seen in chicken manure, followed by vermicompost and cattle manure. This showed chicken manure was decomposed at a faster rate than the others. Also, contrast analysis showed the application of organic amendments significantly increased TSOC at both weeks. However, TSOC was not significantly different from others. Therefore, each amendment contributed an equal amount of organic matter to the soil. 


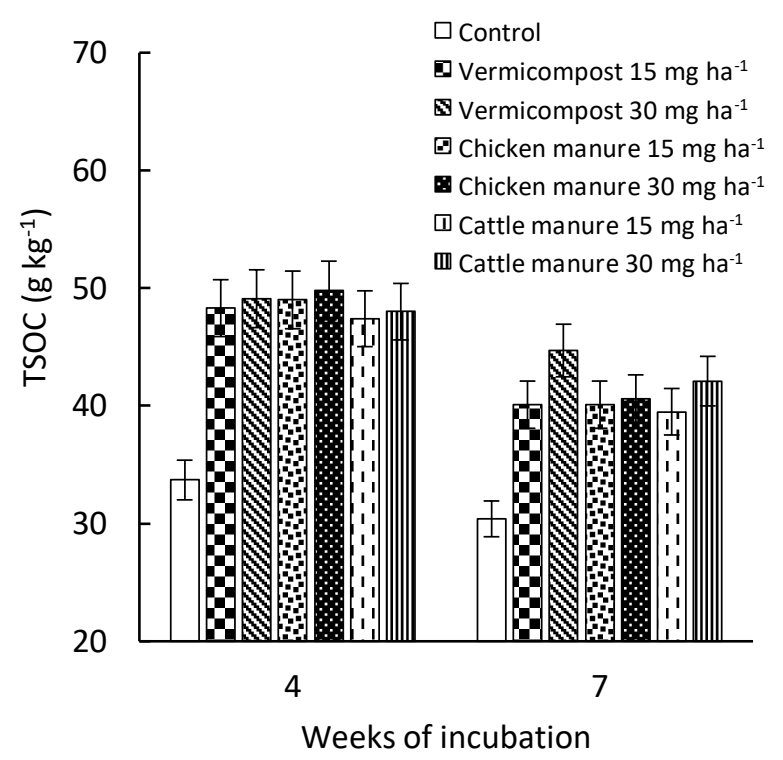

Figure 3. Total soil organic carbon under application of the organic amendment

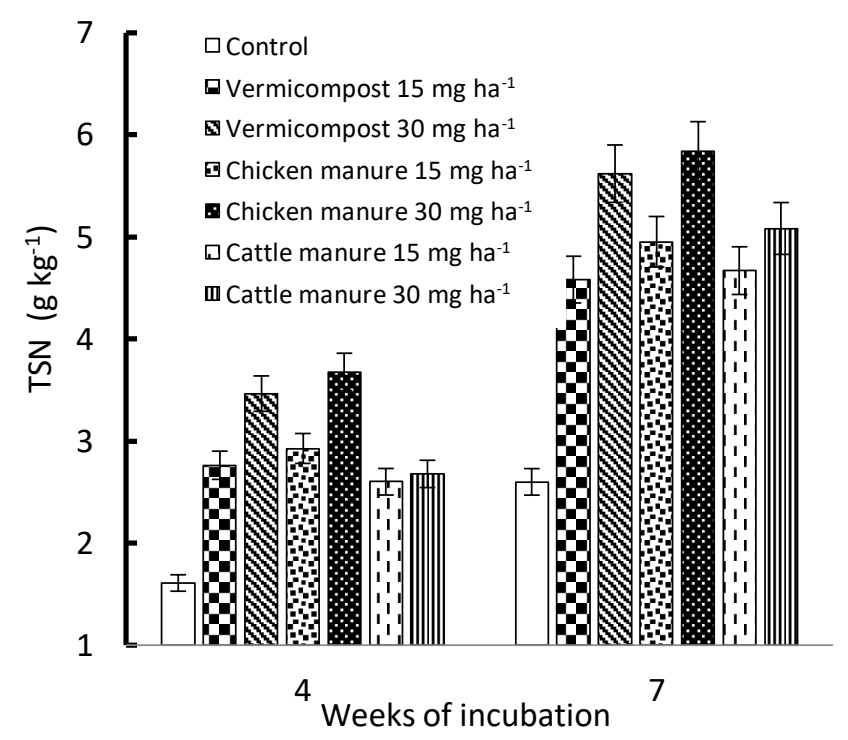

Figure 4. Total soil nitrogen at week 4 and 7 as affected by organic amendment

\subsection{Total soil nitrogen}

In contrast to TSOC, TSN was significantly higher at week 7 than 4, as shown in Figure 4. The application of cattle manure reached the highest TSN, even though at the end of the incubation, chicken manure still had the highest TSN. Each form of organic amendments markedly increased TSN for both weeks. At week 4, TSN was increased by $93.5 \%, 105.2 \%$, and $64.0 \%$ for vermicompost, chicken, and cattle manure respectively. At the end of the incubation, the percentage was $96.2 \%, 107.5 \%$, and $94.0 \%$ respectively. Nevertheless, TSN was not different among the treatments. A higher rate of organic amendments showed more TSN, but not significant at the $4^{\text {th }}$ incubation week.

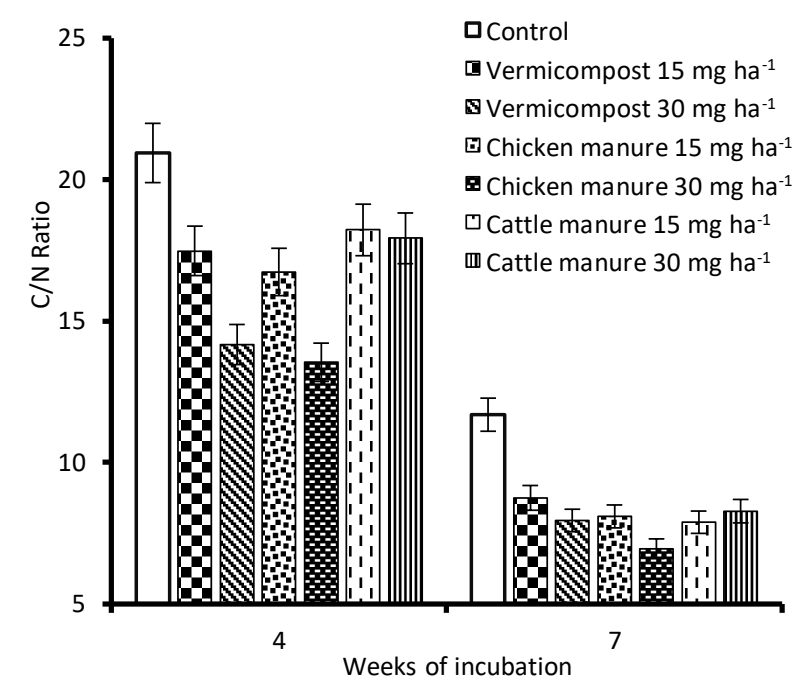

Figure 5. Carbon and nitrogen ratio at 4 and 7 weeks of incubation

\subsection{Carbon and nitrogen ratio}

A significant reduction in $\mathrm{C} / \mathrm{N}$ ratio was observed at week 7 as compared to 4 (Figure 5). The decrease in its ratio was an indication of the decomposition process during incubation. On average, the ratio was lower at the end of incubation compared to week 4. Furthermore, the soil treated with the organic amendments had a significantly lower $\mathrm{C} / \mathrm{N}$ ratio than that of control. Contrast analysis confirmed that organic application considerably lowered soil $\mathrm{C} / \mathrm{N}$ ratio by $34.1 \%$. However, the ratio was not different among other amendments.

\subsection{Exchangeable Aluminum}

At the end of incubation, Ultisols treatment substantially reduced exchangeable $\mathrm{Al}$ as seen in Figure 6 . Contrast analysis showed soil treated with chicken manure, vermicompost, and cattle manure lowered the exchangeable Al by $33.4 \%, 20.9 \%$, and $43.0 \%$ respectively. This result showed cattle manure was the most effective in lowering exchangeable Al, followed by chicken manure and vermicompost. Meanwhile, a higher rate of organic amendments markedly reduced exchangeable Al by $16.4 \%$.

\subsection{Cation Exchange Capacity}

After the $7^{\text {th }}$ week, the organic amendments generally increased the CEC of Ultisols (Figure 7). However, only chicken manure showed a significant increase in CEC. Also, soil treated with chicken manure showed $14.2 \%$ higher CEC than control but was not different from those treated with vermicompost or cattle manure. This showed chicken manure was more effective in improving soil CEC than the other two organic amendments. Meanwhile, the application rate of 30 $\mathrm{Mg} \mathrm{ha}{ }^{-1}$ resulted in a higher CEC than $15 \mathrm{Mg} \mathrm{ha}^{-1}$, therefore, achieving an increase of $12.4 \%$. 


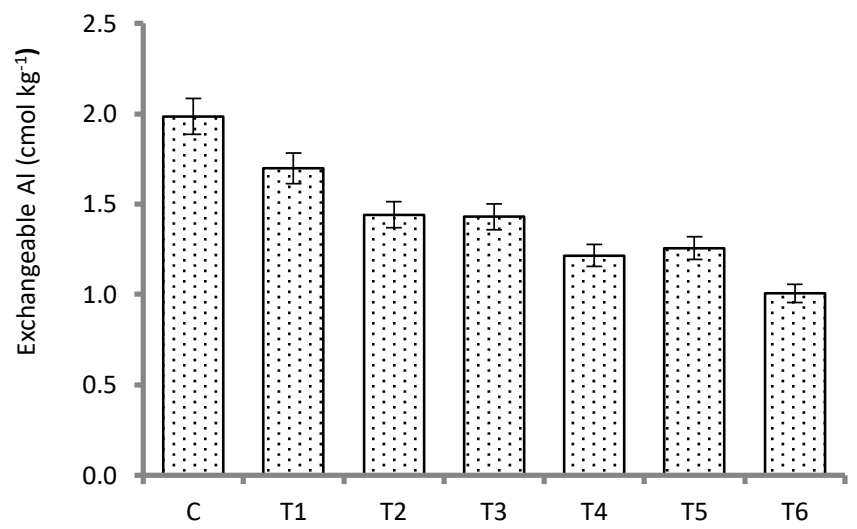

Figure 6. Exchangeable Al after 7 weeks of incubation as affected by organic amendments.

\section{Discussion}

The application of the organic amendments eventually released plant nutrients to the soil. This study showed that the amendments increased $P$ availability in Ultisols until the end of incubation. The result is attributed to the decomposition of organic matter as indicated by a reduction in TSOC and soil $\mathrm{C} / \mathrm{N}$ ratio during incubation. Organic matter is presumably decomposed in the presence of a phosphatase enzyme, which has a significant role in destroying organic- $P$ (Bhat et al., 2017; Salam, 2014). The result of a study by Melero et al. (2008) showed that phosphatase activities were much higher in organically fertilized soil than control. Also, the phosphorus released from organic-P through biochemical mineralization is highly dependent on the released element (McGill \& Cole, 1981). Meanwhile, an increase in P availability is also associated with phosphate release which is common in acid soil such as Ultisols. Figure 6 showed a significant reduction in exchangeable $\mathrm{Al}$ after 7 weeks of soil and amendment incubation. A humic substance with a high carboxyl and the phenolic group is responsible for the formation of the organometallic complex of Al and Fe, which released phosphate to the soil solution. Sparks (2003) stated that $\mathrm{Fe}$ and $\mathrm{Al}$ compete for the binding sites of ligand, particularly carboxyl. Earlier studies showed an increase in $P$ after treating the soil with humic acid (Ifansyah, 2013). The result was similar to that reported by Hamed et al. (2014) in which the application of selected organic material significantly increased $P$ in calcareous soil during 60 days of incubation and decreased after 120 days. Another study by Amanullah (2007) confirmed that the $P$ content of poultry manure increased steadily from 15 to 75 days of the incubation.

This study also showed that the increase of $P$ in the first 3 weeks is lesser when compared with subsequent weeks. This phenomenon can be associated with the lower microorganisms development at the early stage of decomposition and possibly immobilization of $\mathrm{P}$ by micro-organisms. Sekiguchi et al. (2007) found that the number of bacteria and fungi did not increase in the first 3 months, followed by a significant increase. This showed low micro-organism development at the early stage of decomposition. Another study also concluded that during decomposition, a portion of

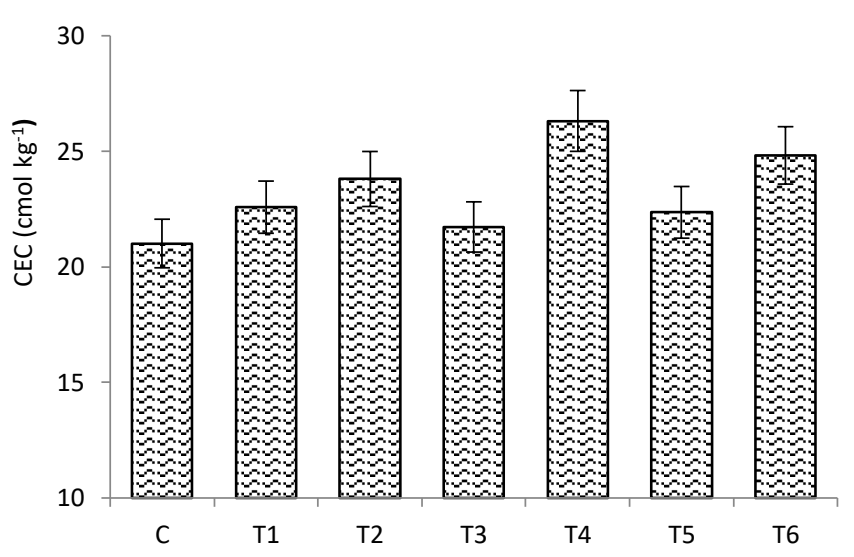

Figure 7. Cation exchange capacity after the incubation as influenced by organic amendments

available $\mathrm{P}$ such as orthophosphate was immobilized into microbial P (Qualls \& Richardson, 2000; Richardson \& Simpson, 2011; L. Zhang et al., 2018). In the next stage, the significant increment of $\mathrm{P}$ may have been related to an increase in the number of decomposed organic matter or dead micro-organisms. According to Richardson \& Simpson (2011), P immobilized by micro-organisms will be available over time. Also, the availability of $P$ during incubation is substantial for plant nutrition. Therefore, considerable attention should be given for the first 3 weeks of incubation. The time of fertilizer application should consider $P$ availability, otherwise $P$ should be applied during the first 3 weeks of growth.

Chicken manure is superior $(p<0.05)$ to vermicompost and cattle manure in contributing $P$ to the soil. This result is related to the $\mathrm{P}$ content of chicken manure which is highest among the amendments as previously shown. Besides, chicken manure is decomposed at a faster rate as indicated from Figure 1 where $P$ increment during incubation was higher than other amendments. On average, available $P$

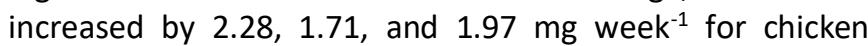
manure, vermicompost, and cattle manure respectively. The previous experiment concluded that in a long term fertilized field, poultry manure contributed higher phosphate to the soil than cattle manure (Li et al., 2011). The superiority of poultry manure in releasing $P$ to the soil was also observed by Agbede \& Adekiya (2016) where the P content of poultry manure fertilized soil was $35.5 \%$ higher than that of cocoa pod ash. Furthermore, the increase in $\mathrm{P}$ of fertilized soil and a higher rate of organic amendments are dependent on the amount of substrate application. Similar results were confirmed by a number of studies (Adeleye et al., 2010; Amanullah et al., 2010; Ewulo et al., 2008; Kobierski et al., 2017; Muktamar et al., 2018; Sianturi et al., 2019).

An increase in $\mathrm{P}$ during decomposition is also confirmed from regression analysis between TSOC and available $P$. This analysis showed that $P$ significantly correlated with TSOC $(p<0.05, r=0.80)$ and the linear relationship of $y=0.62 X-0.05$. The result also showed decomposition from organic matter considerably released $\mathrm{P}$ to the soil. The correlation also implied that a higher amount of organic matter indicated by TSOC will linearly increase $P$ in the soil. 
Furthermore, this study showed that soil $\mathrm{pH}$ was significantly increased with the treatment of organic amendments. However, there was no difference between the types of organic amendments. The decomposition produced stable humic substances rich in functional groups mainly carboxyl and phenolic. The functional groups formed organo complex with metals such as Al (Sposito, 2008; Wong \& Swift, 2001) as indicated by a decrease in exchangeable Al at the end of incubation. This led to lower proton production in soil (higher $\mathrm{pH}$ ). Earlier studies observed similar results where the application of organic fertilizer enhanced soil $\mathrm{pH}$ and lowered the exchangeable Al of acidic soil (Anggita et al., 2018; Sianturi et al., 2019).

Proton dissociation from functional groups contributed to the negative charge of the soil (Sparks, 2003; X. N. Zhang \& Zhao, 1997). This was indicated by an increase in soil CEC, especially chicken manure treatment. On the other hand, all organic amendments substantially lowered exchangeable Al. This result showed the formation of the Al organic complex had occurred before increasing the CEC of the soil. Wong \& Swift (2001) also emphasized that the drastic reduction of $\mathrm{Al}$ solubility was observed at a $\mathrm{pH}$ of 3-4 for both Oxisols and Ultisols. Meanwhile, there were no significant effects of vermicompost and cattle manure on CEC. This may be associated with a slight increase in $\mathrm{pH}$, in which the highest was obtained from chicken manure of $30 \mathrm{Mg}$ ha, ${ }^{-1}$ which was approximately 4.82 after 7 weeks. This $\mathrm{pH}$ value is close to the PZC of humic substances. According to Sparks (2003), soil organic matter had PZC of about 3. Also, some research confirmed a significant contribution of soil organic matter on CEC (Bohn et al., 2001; Sposito, 2008; Tan, 2011).

\section{Conclusion}

The treatment of organic amendments on Ultisols had significant $(p<0.05)$ improvement on $P$. The availability of phosphorus was sluggish during the first 3 weeks and was later substantial. The result was significant to $P$ fertilization using organic fertilizer. The time of application is mainly to ensure nutrient provision at an early stage. Meanwhile, chicken manure was superior to vermicompost and cattle manure in contributing P. Also, the organic amendments enhanced the chemical properties of Ultisols as indicated by an increase in TSN, soil pH, and the reduction of exchangeable Al. In general, chicken manure provided better soil improvement when compared to vermicompost and cattle manure. Therefore, this result is beneficial for $P$ management in Ultisols.

\section{Acknowledgments}

Sincere appreciation goes to the University of Bengkulu for providing the facilities and other necessary resources. Acknowledgment is also extended to the technicians at Soil Science Laboratory, Faculty of Agriculture, University of Bengkulu for assisting with soil analysis.

\section{Declaration of Competing Interest}

The authors declare no competing financial or personal interests that may appear and influence the work reported in this paper.

\section{References}

Adeleye, E., Ayeni, L., \& Ojeniyi, S. (2010). Effect of poultry manure on soil physico-chemical properties, leaf nutrient contents, and yield of yam (Dioscorea rotundata) on alfisol in southwestern Nigeria. Journal of American Science, 6(10), 871-878.

Agbede, T. M., \& Adekiya, A. O. (2016). Effect of cacao pod ash and poultry manure on soil properties and cocoyam productivity of nutrient-depleted tropical Alfisol. International Journal of Agricultural and Biosystems Engineering, 10(3), 172-179.

Amanullah, M. M. (2007). Nutrient release pattern during composting poultry manure. Research Journal of Agriculture and Biological Sciences, 3(4), 306-308.

Amanullah, M. M., Sekar, S., Muthukrishnan, P., \& others. (2010). Prospects and potential of poultry manure. Asian Journal of Plant Sciences, 9(4), 172-182.

Anggita, T., Muktamar, Z., \& Fahrurrozi, F. (2018). Improvement of selected Soil chemical properties and potassium uptake by mung beans after application of liquid organic fertilizer in Ultisol. TERRA: Journal of Land Restoration, 1(1), 1-7.

Balai Penelitian Tanah. (2009). Analisis Kimia Tanah, Tanaman, Air, dan Pupuk (Second). Balai Besar Litbang Sumberdaya Lahan Pertanian.

Bhat, N. A., Riar, A., Ramesh, A., Iqbal, S., Sharma, M. P., Sharma, S. K., \& Bhullar, G. S. (2017). Soil biological activity contributing to phosphorus availability in vertisols under long-term organic and conventional agricultural management. Frontiers in Plant Science, 8 , 15-23.

Bohn, H. L., McNeal, B. L., \& O'Connor, G. A. (2001). Soil Chemistry. John Wiley \& Sons.

Dotaniya, M., Datta, S., Biswas, D., \& Kumar, K. (2014). Effect of organic sources on phosphorus fractions and available phosphorus in Typic Haplustept. Journal of the Indian Society of Soil Science, 62(1), 80-83.

Ewulo, B., Ojeniyi, S., \& Akanni, D. (2008). Effect of poultry manure on selected soil physical and chemical properties, growth, yield, and nutrient status of tomato. African Journal of Agricultural Research, 3(9), 612-616.

Fahrurrozi, F., Muktamar, Z., Dwatmadji, D., Setyowati, N., Sudjatmiko, S., \& Chozin, M. (2016). Growth and yield responses of three sweet corn (Zea mays L. var. saccharata) varieties to local-based liquid organic fertilizer. International Journal on Advanced Science Engineering Information Technology, 6(3), 319-323. https://doi.org/10.18517/ijaseit.6.3.730

Hamed, M. H., Desoky, M., Ghallab, A., \& Faragallah, M. (2014). Effect of Incubation Periods and Some Organic Materials on Phosphorus Forms in Calcareous Soils. Int. J. of Tech. Enhancement and Emerging Eng. Research, 2(6), 108-118.

Ifansyah, H. (2013). Soil pH and solubility of aluminum, iron, and phosphorus in ultisols: The roles of humic acid. Journal of Tropical Soils, 18(3), 203-208.

Kobierski, M., Bartkowiak, A., Lemanowicz, J., \& Piekarczyk, M. (2017). Impact of poultry manure fertilization on 
chemical and biochemical properties of soils. Plant, Soil, and Environment, 63(12), 558-563. DOI: 10.17221/668/2017-PSE.

Li, J., Zhong, X., Wang, F., \& Zhao, Q. (2011). Effect of poultry litter and livestock manure on soil physical and biological indicators in a rice-wheat rotation system. Plant, Soil, and Environment, 57(8), 351-356.

McGill, W., \& Cole, C. (1981). Comparative aspects of cycling of organic $C, N, S$, and $P$ through soil organic matter. Geoderma, 26(4), 267-286.

Melero, S., Madejón, E., Herencia, J. F., \& Ruiz, J. C. (2008). Effect of implementing organic farming on chemical and biochemical properties of an irrigated loam soil. Agronomy Journal, 100(1), 136-144.

Mohammadi, S., Kalbasi, M., \& Shariatmadari, H. (2009). Cumulative and residual effects of organic fertilizer application on selected soil properties, water soluble $\mathrm{P}$, Olsen-p, and P sorption index. J. Agr. Sci. Tech, 11, 487497.

Muktamar, Z, Adiprasetyo, T., Yulia, Sari, L., Suprapto, Fahrurrozi, F., \& Setyowati, N. (2018). Residual effect of vermicompost on sweet corn growth and selected chemical properties of soils from different organic farming practices. International Journal of Agricultural Technology, 14(7), 1471-1482.

Muktamar, Z, Justisia, B., \& Setyowati, N. (2016). Quality enhancement of humid tropical soils after application of water hyacinth (Eichornia crassipes) compost. Journal of Agricultural Technology, 12(7.1), 1211-1228.

Muktamar, Z., Sudjatmiko, S., Chozin, M., Setyowati, N., \& Fahrurrozi, F. (2017). Sweet corn performance and its major nutrient uptake following application of vermicompost supplemented with liquid organic fertilizer. International Journal on Advanced Science Engineering Information Technology, 7(2), 602-608.

Peng, X., Ye, L., Wang, C., Zhou, H., \& Sun, B. (2011). Temperature-and duration-dependent rice strawderived biochar: Characteristics and its effects on soil properties of an Ultisol in southern China. Soil and Tillage Research, 112(2), 159-166. DOI:10.1016/j.still.2011.01.002

Prasetyo, B., \& Suriadikarta, D. (2006). Karakteristik, potensi, dan teknologi pengelolaan tanah ultisol untuk pengembangan pertanian lahan kering di Indonesia. Jurnal Litbang Pertanian, 25(2), 39-47.

Qualls, R. G., \& Richardson, C. J. (2000). Phosphorus enrichment affects litter decomposition, immobilization, and soil microbial phosphorus in wetland mesocosms. Soil Science Society of America Journal, 64(2), 799-808.
Richardson, A. E., \& Simpson, R. J. (2011). Soil microorganisms mediating phosphorus availability update on microbial phosphorus. Plant Physiology, 156(3), 989-996. DOI: https://doi.org/10.1104/pp.111.175448.

Rita, J. C. de O., Gama-Rodrigues, A. C., Gama-Rodrigues, E. F., Zaia, F. C., \& Nunes, D. A. D. (2013). Mineralization of organic phosphorus in soil size fractions under different vegetation covers in the north of Rio de Janeiro. Revista Brasileira de Ciência Do Solo, 37(5), 1207-1215.

Salam, A. K. (2014). Enzymes in Tropical Soils. Global Madani Press.

Sekiguchi, H., Kushida, A., \& Takenaka, S. (2007). Effect of cattle manure and green manure on the microbial community structure in upland soil determined by denaturing gradient gel electrophoresis. Microbes Environment, 22(4), 327-335. https://www.jstage.jst.go.jp/article/jsme2/22/4/22_07 123/_pdf

Seufert, V., Ramankutty, N., \& Foley, J. A. (2012). Comparing the yields of organic and conventional agriculture. Nature, 485(7397), 229-232. DOI:10.1038/nature11069.

Sianturi, S. M., Muktamar, Z., \& Chozin, M. (2019). Enhancing Soil Chemical Properties and Sweet Corn Growth by Solid Organic Amendments in Ultisol. TERRA: Journal of Land Restoration, 2(1), 1-8. DOI: https://doi.org/10.31186/terra.2.1.1-8.

Sparks, D. L. (2003). Environmental Soil Chemistry. Elsevier. Sposito, G. (2008). The Chemistry of Soils (Second Ed.). Oxford University Press.

Tan, K. H. (2011). Principles of Soil Chemistry. CRC press.

Tennakoon, N., \& Bandara, S. H. (2003). Nutrient content of some locally available organic materials and their potential as alternative sources of nutrients for coconut. Cocos, 15, 23-30.

Wong, M., \& Swift, R. (2001). Application of fresh and humified organic matter to ameliorate soil acidity. Proceedings of the 9th International Conference of the International Humic Substance Society. Understanding and Managing Organic Matter in Soils, Sediments, and Water, 235-242.

Zhang, L., Ding, X., Peng, Y., George, T. S., \& Feng, G. (2018). Closing the loop on phosphorus loss from intensive agricultural soil: A microbial immobilization solution? Frontiers in Microbiology, 9, 104. DOI: https://doi.org/10.3389/fmicb.2018.00104.

Zhang, X. N., \& Zhao, A. Z. (1997). Surface Charge. In Chemistry of Variable Charge Soils (pp. 17-63). Oxford University Press. 